\title{
Knowledge, Attitude, Practice, and Concerns of Non-Medical Students in Surabaya Against Covid-19 Vaccination
}

\author{
Alyaa Ulaa Dhiya Ul Haq ${ }^{a}$, Sinta Dwi Juniara, Vida Cahlia Novita Sari ${ }^{a}$, Danti Nur \\ Indiastuti ${ }^{\mathrm{b} *}$ \\ *danti-n-i@fk.unair.ac.id \\ ${ }^{a}$ Medical Program, Faculty of Medicine, Universitas Airlangga, Surabaya, Indonesia \\ ${ }^{b}$ Department of Anatomy, Histology and Pharmacology, Division of Pharmacology, \\ Faculty of Medicine, Universitas Airlangga, Surabaya, Indonesia
}

\begin{abstract}
Introduction: COVID-19 vaccination has been carried out for the elderly, traders, vulnerable groups, and the government has also begun to accelerate vaccination for residents aged 18 years and over. Regarding this issue, we seek to assess college students' understanding of the knowledge about the vaccinations they will receive.

Method: Survey on the level of knowledge, attitudes, practices, and concerns regarding vaccination was assisted by using the Knowledge, Attitude, Practices and Concerns (KAPC) questionnaire with a reliability value of Cronbach's Alpha coefficient of 0.86 which indicates that the questionnaire has good consistency and the validation of the questionnaire also shows good result. Respondents are non-medical students who live in Surabaya which are $\geq 18$ years old and obtained by total sampling. Data analysis for the level of knowledge using the scale method, namely the Guttman scale. Meanwhile, the components of attitudes, practices, and concerns were measured using a Likert scale.
\end{abstract}

Results: Sociodemographic data showed that the majority of respondents were 21 years old, amounting to $58.1 \%$. Most respondents are female with a percentage of $67.6 \%$. The results of the knowledge of non-medical students in Surabaya for the Covid-19 vaccination showed that 105 respondents had a level of 54.3\%. Respondents' attitudes against COVID-19 vaccination are valued as much as $81.2 \%$. The respondents' practice of COVID-19 vaccination is $78.8 \%$. Meanwhile, the level of concern of respondents regarding the COVID-19 vaccination is $34.4 \%$.

Conclusion: Based on survey data as many as 105 respondents from non-medical students in Surabaya regarding the COVID-19 vaccination, it is known that the respondents' knowledge level is low, the respondent's attitude is very good, the respondent's practice level is good, and the respondent's level of concern about COVID-19 vaccination barriers is low.

Keywords: Knowledge, Attitude, Practice, Concern, Vaccination, COVID-19

\section{Introduction}

Coronavirus disease 2019 (COVID-19) is a disease caused by Severe Acute Respiratory Syndrome Coronavirus 2 (SARS-CoV-2), a new variant of the coronavirus family that has never been identified before [1]. Currently, the whole world, including Indonesia, is experiencing an outbreak of disease caused by SARS-CoV-2. In addition to having an impact on the health sector, this pandemic also has an impact on other sectors such as the economy, socio-culture, tourism, food or agriculture, 
and even transportation. According to the WHO, COVID-19 can cause disease with mild symptoms or even asymptomatic to very severe symptoms. The absence of a drug that has been found makes us have to do the best possible prevention to not get infected [2]. Data on July 22, 2021 states that the condition of COVID-19 in Indonesia has touched 3.03 million cases with the addition of 49,509 new cases [3].

In addition to the implementation of health protocols that have been intensified, the presence of the COVID-19 vaccine is a breath of fresh air for the world community in the midst of this pandemic. Vaccines are biological products that are given to a person to protect the body from a debilitating, even life-threatening disease. Vaccines stimulate the formation of immunity against certain diseases in a person's body. The body will remember the virus or disease-causing bacteria, recognize and know how to fight it. As with the benefits of other vaccines, the COVID-19 vaccine is useful for protecting the body from falling ill due to COVID-19 by generating or stimulating specific immunity in the body by administering a vaccine [2]. The priority group for vaccine recipients is residents who are domiciled in Indonesia and 18 years of age or older [1].

A survey conducted by the Ministry of Health and the Indonesian Technical Advisory Group on Immunization (ITAGI) revealed that the majority of the public were concerned about the safety and effectiveness of vaccines, expressed distrust of vaccines, and questioned the halalness of vaccines. Around $65 \%$ of respondents said they were willing to accept the COVID-19 vaccine if provided by the Government, while $8 \%$ of them refused, and the remaining $27 \%$ expressed doubts about the Government's plan to distribute the COVID-19 vaccine [4]. Doubts arise from some people who are afraid of needles and who have experienced side effects after being immunized. Many people do not believe that COVID-19 (SARS-CoV-2) is real or that it is possible to spread and threaten public health. Some people claim that the pandemic is a product of propaganda, conspiracy, hoax, and/or a deliberate attempt to spread fear through the media for profit [4]. Therefore, understanding the benefits of the COVID-19 vaccine to the community consistently and continuously, and touching all levels of society is very important.

COVID-19 vaccination has been carried out for the elderly, traders, and vulnerable groups. The government has also begun to accelerate vaccination for residents aged 18 years and over. Online registration for vaccination of citizens aged 18 years and over has also been informed. Regarding this issue, we seek to assess college students' understanding of the knowledge about the vaccinations they will receive. This is important because now the target of vaccination is people aged 18 years and over.

\section{Research Elaboration}

Survey on the level of knowledge, attitudes, practices, and concerns regarding vaccination was assisted by using the Knowledge, Attitude, Practices and Concerns (KAPC) questionnaire with a reliability value of Cronbach's Alpha coefficient of 0.86 which indicates that the questionnaire has good consistency and the validation of the questionnaire also shows good result. This questionnaire consists of two parts. The first part of the questionnaire consisted of questions related to the sociodemographic profile and about getting the COVID-19 vaccine. The second part of the questionnaire consists of matters relating to knowledge about the COVID-19 vaccine and sources of information, assessing people's attitudes, perceptions, and concerns (drivers and barriers) about the COVID-19 vaccine with a total of 39 questions [5]. Respondents are non-medical students who live in Surabaya which are $\geq 18$ years old and obtained by total sampling. Data analysis for the level of knowledge using the scale method, namely the Guttman scale. Meanwhile, the components of 
attitudes, practices, and concerns were measured using a Likert scale.

\section{Results}

Table 1. Sociodemographic Data

\begin{tabular}{|c|c|c|}
\hline \multicolumn{2}{|c|}{ Characteristics } & \multirow{2}{*}{$\begin{array}{c}\text { Percentage } \\
\text { N (\%) } \\
1(1)\end{array}$} \\
\hline Age & 18 & \\
\hline & 19 & $5(4.8)$ \\
\hline & 20 & $27(25.7)$ \\
\hline & 21 & $61(58.1)$ \\
\hline & 22 & $8(7.6)$ \\
\hline & 23 & $3(2,9)$ \\
\hline \multirow[t]{2}{*}{ Gender } & Male & $34(32.4)$ \\
\hline & Female & $71(67.6)$ \\
\hline \multirow[t]{7}{*}{ Universities } & Universitas Airlangga & $37(35.2)$ \\
\hline & ITS & $25(23.8)$ \\
\hline & UNESA & $11(10.5)$ \\
\hline & PPNS & (7) 6.7 \\
\hline & UBAYA & $5(4.8)$ \\
\hline & ITB & $4(3.8)$ \\
\hline & Others & $16(15.2)$ \\
\hline
\end{tabular}


Sociodemographic data showed that the majority of respondents were 21 years old, amounting to $58.1 \%$. Most respondents are female with a percentage of $67.6 \%$. The universities from which the most respondents were Universitas Airlangga, which was $32.5 \%$, followed by ITS as much as $23.8 \%$. Data can be seen in table 1.

Table 2. Percentage of Respondents' Knowledge of COVID-19 Vaccination

\begin{tabular}{llll}
\hline No & Questions Aspects of Knowledge $(\mathrm{N}=105)$ & $\begin{array}{c}\text { Correct Answer } \\
\mathrm{N}(\%)\end{array}$ & $\begin{array}{c}\text { Wrong Answer } \\
\mathrm{N}(\%)\end{array}$ \\
\hline $\mathbf{1}$ & It is legally mandatory to take COVID-19 vaccine. & $26(24.8)$ & $79(75.2)$ \\
\hline
\end{tabular}

Below are various groups of individuals who are eligible/not eligible to receive the COVID-19 vaccine. Give an answer regarding the eligibility of each group to receive the COVID-19 vaccine according to your opinion!

\begin{tabular}{llcc}
\hline $\mathbf{2}$ & Infant <1 years of age & $71(67.6)$ & $34(32.4)$ \\
\hline $\mathbf{3}$ & Children and adolescents under 18 years & $83(79.0)$ & $22(21.0)$ \\
\hline $\mathbf{4}$ & Adults over 18 years & $103(98.0)$ & $2(2.0)$ \\
\hline $\mathbf{5}$ & Pregnant women and breastfeeding mothers & $40(38.0)$ & $65(62.0)$ \\
\hline $\mathbf{6}$ & $\begin{array}{l}\text { Patients with chronic diseases such as diabetes, } \\
\text { hypertension, and heart disease }\end{array}$ & $22(21.0)$ & $83(79)$ \\
\hline $\mathbf{7}$ & Persons having active COVID-19 infection & $84(80.0)$ & $21(20.0)$ \\
\hline $\mathbf{8}$ & Persons recovered from COVID-19 infection & $80(76.2)$ & $25(23.8)$ \\
\hline $\mathbf{9}$ & People who have food/drug allergies & $24(22.9)$ & $81(77.1)$ \\
\hline $\mathbf{1 0}$ & Immunocompromised patients & $52(49.5)$ & $53(50.5)$ \\
\hline $\mathbf{1 1}$ & $\begin{array}{l}\text { Protective immunity against COVID-19 infection will be } \\
\text { achieved after }\end{array}$ & $42(40.0)$ & $63(60.0)$ \\
\hline & & 627 & $57(54.3)$ \\
\hline
\end{tabular}

Table 2 shows the percentage of respondents' knowledge of COVID-19 vaccination. From the table above, it was found that $67.6 \%$ of respondents answered correctly that infants under 1 year of age were not eligible to receive the COVID-19 vaccine. As many as $79 \%$ of respondents answered correctly that children and adolescents under 18 years old are eligible to receive COVID-19 vaccine. 98\% of respondents answered correctly that adults over the age of 18 are eligible to receive the COVID-19 vaccine. However, only $38 \%$ of respondents answered correctly that pregnant women and breastfeeding 
mothers are not eligible to receive the COVID-19 vaccine. As many as $21 \%$ of respondents answered correctly that patients with chronic diseases such as diabetes, hypertension, and heart disease deserve to receive the COVID-19 vaccine. The next result is that $80 \%$ of respondents answered correctly if people who are suffering from an active COVID-19 infection are not eligible to receive the COVID-19 vaccine. As many as $76.2 \%$ of respondents answered correctly if people who have recovered from COVID-19 infection are eligible to receive the COVID-19 vaccine. A total of $22.9 \%$ of respondents answered correctly if people who have food/drug allergies are eligible to receive the COVID-19 vaccine. $49.5 \%$ of respondents answered correctly that immunocompromised (immune deficient) patients are not eligible to receive the COVID-19 vaccine. It was also found that $40 \%$ of respondents answered correctly if immune protection against COVID-19 infection would be obtained after the second dose of vaccination was given.

\begin{tabular}{|c|c|c|c|c|c|c|}
\hline No & Question & $\begin{array}{l}\text { Strongly } \\
\text { Disagree } \\
\mathrm{N}(\%)\end{array}$ & $\begin{array}{l}\text { Disagree } \\
\mathrm{N}(\%)\end{array}$ & $\begin{array}{l}\text { Neutral } \\
\mathrm{N}(\%)\end{array}$ & $\begin{array}{l}\text { Agree } \\
\text { N }(\%)\end{array}$ & $\begin{array}{l}\text { Strongly } \\
\text { Agree } \\
\mathrm{N}(\%)\end{array}$ \\
\hline 1 & $\begin{array}{l}\text { When my turn of vaccination comes, I am } \\
\text { willing to take the COVID-19 vaccine }\end{array}$ & $1(1.0)$ & $\begin{array}{c}1 \\
(1.0)\end{array}$ & $10(9.5)$ & $\begin{array}{c}31 \\
(29,5)\end{array}$ & $62(59.0)$ \\
\hline 2 & $\begin{array}{l}\text { I would prefer to acquire immunity against } \\
\text { COVID-19 naturally (by having the } \\
\text { disease/subclinical infection) rather than by } \\
\text { vaccination }\end{array}$ & $28(26.7)$ & $33(31.4)$ & $35(33.3)$ & $5(4.8)$ & $4(3.8)$ \\
\hline 3 & $\begin{array}{l}\text { I am willing to get the COVID-19 vaccine, } \\
\text { even if I have to pay to get it. }\end{array}$ & $7(6.7)$ & $15(14.3)$ & $29(27.6)$ & $42(40.0)$ & $12(11.4)$ \\
\hline 4 & $\begin{array}{l}\text { I would recommend my family and friends to } \\
\text { get vaccinated against COVID- } 19 \text {. }\end{array}$ & $1(1.0)$ & $\begin{array}{c}2 \\
(1.9)\end{array}$ & $10(9.5)$ & 49 (46.7) & $43(41.0)$ \\
\hline 5 & $\begin{array}{l}\text { After getting COVID-19 vaccine, I don't need } \\
\text { to follow preventive measures such as wearing } \\
\text { a mask, sanitisation and social distancing. }\end{array}$ & 72 (68.6) & $26(24.8)$ & $\begin{array}{c}2 \\
(1.9)\end{array}$ & $1(1.0)$ & $4(3.8)$ \\
\hline
\end{tabular}

From the survey results, it is known that based on the attitude of the respondents towards the COVID-19 vaccination, 59\% of the respondents strongly agree to receive the COVID-19 vaccination when the vaccination schedule has arrived. A total of $40 \%$ of all respondents said they agreed to receive the COVID-19 vaccination even though they had to pay. A total of $46.7 \%$ of respondents agreed to recommend their family and friends to participate in getting the COVID-19 vaccination. From all the respondents, $72 \%$ of them strongly disagreed with the attitude of disobeying health protocols after receiving the COVID-19 vaccine. Data can be seen in table 3 . 


\begin{tabular}{|c|c|c|c|c|c|c|c|c|c|c|c|}
\hline \multirow{2}{*}{$\begin{array}{l}\text { No. } \\
1\end{array}$} & \multirow{2}{*}{$\begin{array}{l}\text { Questions } \\
\text { I think there is no harm in } \\
\text { taking COVID-19 vaccine. }\end{array}$} & \multicolumn{2}{|c|}{$\begin{array}{l}\text { Strongly } \\
\text { Disagree } \\
\mathrm{N}(\%)\end{array}$} & \multicolumn{2}{|c|}{$\begin{array}{l}\text { Disagree } \\
\mathrm{N}(\%)\end{array}$} & \multicolumn{2}{|c|}{$\begin{array}{l}\text { Neutral } \\
\mathrm{N}(\%)\end{array}$} & \multicolumn{2}{|c|}{$\begin{array}{l}\text { Agree } \\
\mathrm{N}(\%)\end{array}$} & \multicolumn{2}{|c|}{$\begin{array}{c}\text { Strongly Agree } \\
\mathrm{N}(\%)\end{array}$} \\
\hline & & 2 & (1.9) & 2 & (1.9) & 15 & (14.3) & 49 & (46.7) & 37 & $(35.2)$ \\
\hline 2 & $\begin{array}{l}\text { I believe the COVID-19 } \\
\text { vaccine will be useful in } \\
\text { protecting me from } \\
\text { COVID-19 infection. }\end{array}$ & 1 & (1) & 4 & (3.8) & 10 & (9.5) & 54 & (51.4) & 36 & $(34.3)$ \\
\hline 3 & $\begin{array}{l}\text { COVID-19 vaccine is } \\
\text { available free of cost. }\end{array}$ & 1 & (1) & 2 & (1.9) & 3 & (2.9) & 41 & $(39.0)$ & 58 & $(55.2)$ \\
\hline 4 & $\begin{array}{l}\text { My healthcare } \\
\text { professional/ doctor has } \\
\text { recommended me. }\end{array}$ & 6 & (5.7) & 20 & (19) & 48 & (45.7) & 31 & $(29.5)$ & 0 & (0) \\
\hline 5 & $\begin{array}{l}\text { I feel the benefits of taking } \\
\text { the COVID-19 vaccine } \\
\text { outweighs the risk } \\
\text { involved. }\end{array}$ & 1 & (1) & 4 & (3.8) & 13 & $(12.4)$ & 49 & $(46.7)$ & 38 & $(36.2)$ \\
\hline 6 & $\begin{array}{l}\text { I believe that taking the } \\
\text { COVID-19 vaccine is a } \\
\text { societal responsibility. }\end{array}$ & 1 & (1) & 3 & (2.9) & 15 & $(14.3)$ & 45 & (42.9) & 41 & (39) \\
\hline 7 & $\begin{array}{l}\text { There is sufficient data } \\
\text { regarding the vaccine's } \\
\text { safety and efficacy released } \\
\text { by the government. }\end{array}$ & 2 & (1.9) & 14 & (13.3) & 29 & $(27.6)$ & 35 & (33.3) & 25 & $(23.8)$ \\
\hline 8 & $\begin{array}{l}\text { Many people are taking the } \\
\text { COVID-19 vaccine. }\end{array}$ & 2 & (1.9) & 12 & (11.4) & 22 & $(21.0)$ & 45 & (42.9) & 24 & $(22.9)$ \\
\hline 9 & $\begin{array}{l}\text { I think it will help in } \\
\text { eradicating } \\
\text { infection. }\end{array}$ & 2 & (1.9) & 4 & (3.8) & 17 & $(16.2)$ & 49 & $(46.7)$ & 33 & $(31.4)$ \\
\hline 10 & $\begin{array}{l}\text { My role } \\
\text { models/political/leaders/se } \\
\text { nior doctors/scientists have } \\
\text { taken COVID-19 vaccine. }\end{array}$ & 2 & (1.9) & 3 & (2.9) & 17 & $(16.2)$ & 51 & $(48.6)$ & 32 & $(30.5)$ \\
\hline
\end{tabular}

Table 4 shows the percentage of respondents' practice of COVID-19 vaccination. A total of $46.7 \%$ of respondents agreed that there was no harm in getting a COVID-19 vaccination and $51.4 \%$ of respondents agreed that the COVID-19 vaccine would be useful in protecting the body from COVID-19 infection. A total of 55.2\% of respondents strongly agree that the COVID-19 vaccine is available for free. $45.7 \%$ of respondents were neutral towards doctors/health experts who recommended getting a COVID-19 vaccination. A total of $46.7 \%$ agreed that the benefits of receiving a COVID-19 vaccination outweigh the disadvantages and $42.9 \%$ of respondents agreed that getting a COVID-19 vaccine is a social responsibility. A total of $33.3 \%$ of respondents agree that the government has released sufficient 
data regarding the safety and effectiveness of vaccination. As many as $42.9 \%$ of respondents agreed that many people had received the COVID-19 vaccination. From the data, $46.7 \%$ of respondents agreed that receiving vaccinations would help reduce COVID-19 infection. A total of $48.6 \%$ of respondents agree that the person who is an example of a senior Doctor/Politician/Researcher has received a COVID-19 vaccination.

Table 5 shows the percentage of respondents' level of concern about COVID-19 vaccination. The majority of respondents disagreed with the concerns that might arise regarding the COVID-19 vaccination. As many as $42.9 \%$ of respondents do not agree that the availability of the COVID-19 vaccine is not easy to access. A total of $37.1 \%$ of respondents were neutral and $34.3 \%$ agreed on the possibility of serious side effects after receiving the COVID-19 vaccination. Of the total respondents, $40.0 \%$ of them disagreed with the concern of getting a defective or fake COVID-19 vaccine. A total of $33.3 \%$ respondents were neutral and $26.7 \%$ agreed that a COVID-19 vaccine was developed and distributed too quickly. The survey showed $37.1 \%$ of respondents were neutral and $34.3 \%$ agreed on the possibility of getting side effects in the future after receiving the COVID-19 vaccination. Regarding concerns about the COVID-19 vaccination being promoted for the commercial benefit of drug and pharmaceutical companies, $30.5 \%$ of respondents disagreed and $29.5 \%$ were neutral.

From the survey results, it is known that 59\% of respondents admitted that news from national $\mathrm{TV} /$ radio had quite an influence on respondents' opinions regarding vaccination. A total of $54.3 \%$ respondents admitted that government agencies have quite an influence on respondents' opinions regarding vaccination. A total of $55.2 \%$ of all respondents admitted that social media such as Facebook, Instagram, Whatsapp, etc. greatly influenced their opinion regarding vaccination. As many as $43.8 \%$ of respondents admitted that discussions with relatives and family had quite an effect on their opinion regarding vaccination. Of the total respondents, $44.8 \%$ of them admitted that health service providers also had a significant influence on respondents' opinions regarding vaccination. Data shown in table 6. 
Table 5. Respondents' Percentage of Concerns About COVID-19 Vaccination

\begin{tabular}{|c|c|c|c|c|c|c|c|c|c|c|c|c|}
\hline No & Question & \multicolumn{2}{|c|}{$\begin{array}{l}\text { Strongly } \\
\text { Disagree } \\
\mathrm{N}(\%)\end{array}$} & \multicolumn{2}{|c|}{$\begin{array}{l}\text { Disagree } \\
\mathrm{N}(\%)\end{array}$} & \multicolumn{2}{|c|}{$\begin{array}{l}\text { Neutral } \\
\mathrm{N}(\%)\end{array}$} & \multicolumn{2}{|c|}{$\begin{array}{l}\text { Agree } \\
\mathrm{N}(\%)\end{array}$} & \multicolumn{3}{|c|}{$\begin{array}{l}\text { Strongly } \\
\text { Agree } \\
\mathrm{N}(\%)\end{array}$} \\
\hline 3 & $\begin{array}{l}\text { The COVID-19 vaccine } \\
\text { may be faulty or fake. }\end{array}$ & 19 & (18.1) & 42 & (40) & 26 & (24.8) & 16 & $(15.2)$ & 2 & & (1.9) \\
\hline 5 & $\begin{array}{l}\text { I might have some } \\
\text { unforeseen future effects of } \\
\text { the COVID-19 vaccine. }\end{array}$ & 12 & (11.4) & 16 & (15.2) & 39 & (37.1) & 36 & (34.3) & 2 & & (1.9) \\
\hline 6 & $\begin{array}{l}\text { The COVID- } 19 \text { vaccine is } \\
\text { being promoted for } \\
\text { commercial gains of } \\
\text { pharmaceutical companies. }\end{array}$ & 24 & (22.9) & 32 & $(30.5)$ & 31 & (29.5) & 13 & (12.4) & 5 & & (4.8) \\
\hline
\end{tabular}

Table 6. Influence of Information Sources on COVID-19 Vaccination

\begin{tabular}{lccc}
\hline \multicolumn{1}{c}{ Source of Information } & \multicolumn{3}{c}{ Large Influence } \\
\cline { 2 - 4 } & $\begin{array}{c}\text { Not Influential } \\
\mathrm{N}(\%)\end{array}$ & $\begin{array}{c}\text { Moderately Influential } \\
\mathrm{N}(\%)\end{array}$ & $\begin{array}{c}\text { Very Influential } \\
\mathrm{N}(\%)\end{array}$ \\
\hline $\begin{array}{l}\text { News from National } \\
\text { TV/Radio }\end{array}$ & $18(17.2)$ & $62(59.0)$ & $25(23.8)$ \\
\hline $\begin{array}{l}\text { Government agencies } \\
\text { Social Media (Facebook, }\end{array}$ & $26(24.8)$ & $57(54.3)$ & $22(20.9)$ \\
\hline $\begin{array}{l}\text { Instagram, Whatsapp, etc.) } \\
\text { Discussion amongst friends } \\
\text { and family }\end{array}$ & $9(8.6)$ & $38(36.2)$ & $58(55.2)$ \\
\hline Healthcare provider & $12(11.4)$ & $46(43.8)$ & $45(42.9)$ \\
\hline
\end{tabular}




\section{Discussion}

Table 6. Percentage of Overall Category Regarding COVID-19 Vaccination

\begin{tabular}{|l|c|c|}
\hline Category & Percentage (\%) & Information \\
\hline Knowledge & 54.3 & Low \\
\hline Attitude & 81.2 & Very Good \\
\hline Practice & 78.8 & Good \\
\hline Concern & 34.4 & Low \\
\hline
\end{tabular}

The results show that 105 respondents had a level of knowledge as much as $54.3 \%$ regarding to COVID-19 vaccine, which means they have low understanding about COVID-19 vaccination. The results obtained in this study are different with research by Islam et al (2021) which stated that the level of knowledge of the COVID-19 vaccine carried out in Bangladesh was 57\% [6]. That is because the knowledge is influenced by education, family, and previous experience of getting vaccines.

The source of information that has the most influence on respondents' opinions on COVID-19 vaccination in our study is social media, which is $55.2 \%$. This is in accordance with research by Audry et al (2020) which states that social media is often used in disseminating information related to COVID-19 compared to other media [7]. This is also supported by research Al Hanawi et al (2020) which also states that the main source of information related to COVID-19 is through social media around $85.8 \%[8]$.

Survey showed that respondents' attitudes against COVID-19 vaccination is very good, namely as much as $81.2 \%$. This is in accordance with the research conducted by Al-Marshoudi et.al. 2021 which got $59.3 \%$ of respondents' attitudes about the COVID-19 vaccine [9]. In another study, it was found that the attitude of respondents towards COVID-19 vaccination was very good by $78 \%$ and reported that patients who had a previous history of COVID-19 were entitled to receive the COVID-19 vaccine [6]. Research conducted in Bangladesh states that public attitudes towards COVID-19 are very important for the government and policy makers to overcome all barriers to vaccine distribution [6]. A positive attitude towards the COVID-19 vaccine can have a major impact on the prevention and transmission of COVID-19 [10].

From the survey results, it was found that the respondents' practice of COVID-19 vaccination was good, namely $78.8 \%$. This is in accordance with research conducted in Saudi Arabia which shows that the practice of the population of Saudi Arabia is very careful. Nearly 95\% of respondents refrained from attending social events, 94\% avoided crowds, and $88 \%$ avoided shaking hands. Respondents adopted good and safe practices, provided educational and outreach materials, to increase public understanding of the disease, and influence behavior change [8]. This is in accordance with the research conducted by Al-Marshoudi et.al. 2021 which also saw that more than half of respondents, around $57 \%$, willing to receive the vaccine, and $84 \%$ of those willing to take the vaccine would commit to taking a second dose as well. In addition, $97.5 \%$ of them will report side effects to health institutions if there are side effects. However, the reason $60 \%$ of them do not want to get the vaccine is because of uncertainty about vaccine safety [9].

From the results of the study, it was found that the level of concern of respondents regarding the COVID-19 vaccination was low at 34.4\%. The results of this study are in line with research by Dodd et al (2020) conducted in Australia and showed that concerns about vaccine side effects were low at $10 \%$ [11]. 
Knowledge scores are measured using the Guttman Scale. Measurement using the Guttman Scale is a quantitative approach in the form of numbers, the Guttman Scale Assessment is research if you want to get a firm answer to a problem asked, and is always made in multiple choices, namely "yes and no", "true and false", "positive and negative ", for the assessment of answers, for example, for positive answers, they are given a score of 1 , while negative answers are given a score of 0 . Thus, if the answer to the question is agree, it is given a score of 1 and disagree, it is given a score of 0 . If the score is converted into a percentage, then logically it can be described for the answer to agree with a score. $1=1 \times 100 \%=100 \%$, and disagreement is given a score of $0=0 \times 0 \%=0 \%$. According to [12]; The results of measuring knowledge can be grouped into 3 categories, namely: Good (76\%$100 \%)$, Enough (56\%-75\%), and Low (<=55\%).

Attitude, practice, and concern score are measured using Likert scale. Likert scale is a set of statements (items) given for the real situation or hypothesis being studied. Respondents were asked to indicate their level of agreement (from strongly disagree to strongly agree) with a given statement (item) on a metric scale [13]. The score obtained is then interpreted according to the interval scale (I), ie, $0 \%-19.99 \%$ : Very bad/very low; 20\% - 39.99\%: not good/low, 40\% - 59.99\%: Enough/sufficient; $60 \%-79.99 \%$ : Good/high; $80 \%-100 \%$ : very good / very high. However, in measuring the value of respondents' concerns, all question items have negative meanings so that the scoring system is inverted [14].

\section{Conclusion}

Based on survey data from 105 respondents of non-medical students in Surabaya regarding the COVID-19 vaccination, it is known that the respondents' knowledge level is low, the respondent's attitude is very good, the respondent's practice level is good, and the respondent's level of concern about COVID-19 vaccination barriers is low.

\section{Acknowledgements}

\section{References}

[1] Indonesian Ministry of Health. Guidelines for the prevention and control of 6 coronavirus disease (covid-19) 5th revision.

[2] World Health Organization. Coronavirus disease (COVID-19) Pandemic. 2020.

[3] Task Force for Handling COVID-19 2021. Data Sebaran COVID-19, https://covid19.go.id/peta-sebaran (2021).

[4] ITAGI. Covid-19 vaccine acceptance survey in Indonesia. 2020.

[5] Kumari A, Ranjan P, Chopra S, et al. Development and validation of a questionnaire to assess knowledge, attitude, practices, and concerns regarding COVID-19 vaccination among the general population. Diabetes Metab Syndr Clin Res Rev.

[6] Islam MS, Siddique AB, Akter R, et al. Knowledge, attitudes and perceptions towards COVID-19 vaccinations: a crosssectional community survey in Bangladesh. BMC Public Health; 21. Epub ahead of print 2021. DOI: 10.1186/s12889-02111880-9.

[7] Audry CL, Putri MR, Hilmi ZMJ, et al. Edukasi Pencegahan Covid-19 Melalui Media Sosial. ABDIPRAJA (Jurnal Pengabdi Kpd Masyarakat) 2020; 1: 130.

[8] Al-Hanawi MK, Angawi K, Alshareef N, et al. Knowledge, Attitude and Practice Toward COVID-19 Among the Public in the Kingdom of Saudi Arabia: A Cross-Sectional Study. Front Public Heal 2020; 8: 1-10.

[9] Al-Marshoudi S, Al-Balushi H, Al-Wahaibi A, et al. Knowledge, attitudes, and practices (Kap) toward the covid-19 vaccine in oman: A pre-campaign cross-sectional study. Vaccines 2021; 9: 1-14.

[10] Papagiannis D, Malli F, Raptis DG, et al. Assessment of Knowledge, Attitudes, and Practices towards New Coronavirus (SARS-CoV-2) of Health Care Professionals in Greece before the Outbreak Period. Int J Environ Res Public Health.

[11] Ayre J, Cvejic E, McCaffery K, et al. Contextualising COVID-19 prevention behaviour over time in Australia: Patterns and long-term predictors from April to July 2020 in an online social media sample. PLoS One 2021; 16: 1-16. 
[12] Arikunto S. Prosedur penelitian suatu pendekatan praktik. Jakarta: Rineka Cipta 2006; 172.

[13] Singh Y. Fundamentals of research methodology and statistics. New Delhi: New Age International., 2006.

[14] Joshi A, Kale S, Chandel S, et al. Likert Scale: Explored and Explained. 